\title{
Simulasi Optimasi Reactive Distillation untuk Membuat Bioaditif (Triasetin) dari Gliserol dan Asam Asetat dengan Katalis Asam Sulfat Menggunakan Software Aspen Plus
}

\author{
Chici Wardiani Prasongko a,1,*, Fitri Ramdani ${ }^{\text {a,2 }}$, Zahrul Mufrodi b,3 \\ ${ }^{a}$ Departemen Teknik Kimia, Fakultas Teknik, Universitas Gadjah Mada, Jalan Grafika No. 2 Kampus UGM, Yogyakarta, 55281 \\ ${ }^{\mathrm{b}}$ Program Studi Teknik Kimia, Fakultas Teknologi Industri, Universitas Ahmad Dahlan Jalan Ringroad Selatan, Tamanan, Banguntapan, Bantul, \\ Yogyakarta, 55166 \\ ${ }^{1}$ chiciwardianip@gmail.com*; ${ }^{2}$ fitryramdani@gmail.com; ${ }^{3}$ zahrul.mufrodi@che.uad.ac.id \\ * corresponding author
}

ARTICLE INFO

Article history

Received April 25, 2019

Revised May 10, 2019

Accepted

Keywords

Glycerol

Bioaditive (Triacetin)

Reactive Distillation

Aspen Plus

\section{ABSTRACT}

Biodiesel is one product to avoid the energy crisis in the front mass. Oil from plants such as oil palm, coconut, jatropha, or used cooking oil produces glycerol as a by-product of about $10 \mathrm{wt} \%$ of biodiesel products. The excess amount of glycerol must be converted into highvalue products. Because if glycerol is not processed properly, the price of glycerol in the market will drop and it will become a waste that can pollute the environment. One of the derivatives of glycerol which has a high value is triacetin which is a good bio-additive as an anti-knock substance in vehicles. From this study, the synthesis of triacetin is from glycerol and acetic acid using sulfuric acid as a catalyst using the Reactive Distillation (RD) process. RD can be used as a reaction place and at the same time as a product refining place. RD can separate water with acetic acid as a distillate product for about $75 \%$ on the bottom product. The bottom product of RD will produce triacetin and other derivatives which will be separated again using the second column to obtain high purity triacetin. The purpose of this study is to simulate using Aspen Plus software to model the optimization of RD with a continuous system. The feed capacity of $96 \%$ glycerol was 4336.4550 $\mathrm{kg} / \mathrm{hour}$ and $98 \%$ acetate acid was $8659.79 \mathrm{~kg} / \mathrm{hour}$ in the liquid phase with the help of a sulfuric acid catalyst of $115.4592 \mathrm{~kg} /$ hour. The feed enters continuously into RD with a temperature of $115{ }^{\circ} \mathrm{C}$ and a pressure of $1 \mathrm{~atm}$. The simulation results show that triacetin products can reach $99 \%$ as many as $10150.8561 \mathrm{~kg} /$ hour with glycerol conversion of $99.8 \%$ and 30 stages in RD. Besides that, the simulation results can also show the flow rate of each stage and the dimensions of RD.

This is an open access article under the CC-BY-SA license.

\section{Pendahuluan}

Seiring dengan laju pertumbuhan penduduk, kebutuhan sumber energi minyak dari bahan bakar fosil semakin lama semakin meningkat namun persediaannya semakin menipis. Pengembangan dan penggunaan bahan bakar alternatif dari sumber daya alam terbaharukan menjadi salah satu pilihan yang diharapkan untuk mengatasi kebutuhan bahan bakar yang semakin meningkat tersebut. Salah satu bahan bakar alternatif yang saat ini digunakan ialah biodiesel yang diproduksi dari berbagai tanaman seperti kelapa sawit [1], minyak kedelai dan mikroalga. Produk biodiesel dari minyak nabati menghasilkan gliserol sebagai produk samping dengan jumlah $10 \mathrm{wt} \%$ dari produk biodiesel yang dihasilkan. Karena masih mengandung komponen air dan bahan pengotor lainnya sehingga menyebabkan nilai ekonominya rendah. Sehingga jumlah glieserol yang berlebih ini perlu diubah menjadi produk yang bernilai tinggi. 
Beberapa alternatif sintesis industri untuk pemanfaatan gliserol, salah satunya adalah proses asetilasi gliserol dan asam asetat. Produk dari proses ini memiliki aplikasi industri besar, seperti triasetin telah digunakan untuk industri kosmetik dan farmasi, sementara monoasetin dan diasetin telah diterapkan di industri kriogenik dan digunakan sebagai bahan baku biodegradable pembuatan poliester [2] [3] [4]. Selain itu, triasetin adalah bahan kimia alternatif yang menjanjikan untuk diubah menjadi bahan bakar aditif [5] [6] [7]. Pencampuran 10\% (b/b) dari triasetin untuk biodiesel dapat memberikan kinerja yang lebih baik dibandingkan dengan biodiesel murni [8].

Penggunaan triasetin sebagai bioaditif ini dapat mengurangi asap knalpot mesin karena pengurangan molekul karbon dalam campuran bahan bakar. Triasetin $\left(\mathrm{C}_{9} \mathrm{H}_{14} \mathrm{O}_{6}\right)$ adalah zat aditif anti-knocking yang baik dan mudah larut dalam biodiesel. Triasetin juga memiliki manfaat untuk menekan ketukan pada mesin, meningkatkan kinerja mesin dan mengurangi emisi. Kombinasi biodiesel dengan 10\% triasetin mengarah ke peningkatan performa mesin dalam semua aspek [9]. Melihat manfaat dari triasetin diperlukan metode yang tepat untuk dapat mengelola dan memanfaatkan gliserol sebagai sumber bahan baku pembuatan bioaditif sehingga dapat mengurangi limbah gliserol secara signifikan.

Dalam beberapa eksperimen yang telah dilakukan, sintesis triasetin dari gliserol dan asam asetat menggunakan katalis asam sulfat telah dilakukan dalam reaktor batch dan menghasilkan konversi gliserol sebesar $96,30 \%$. Namun membutuhkan waktu yang cukup lama, biaya yang cukup besar dan percobaan yang berulang-ulang untuk mendapatkan hasil yang maksimal. Untuk meminimalisir dan memberikan efisiensi dalam proses penelitian, digunakan sebuah software Aspen Plus, yang diharapkan mampu memberikan kondisi optimasi dari unit reactive distillation sistem kontinyu. Dimana unit reactive distillation dapat digunakan sebagai tempat reaksi dan pemurnian produk. Unit reactive distillation dapat memisahkan air dan asam asetat dengan reaksi produk distilat sekitar $75 \%$ pada hasil produk bottom atas. Produksi menggunakan unit reactive distillation secara kontinyu menghasilkan konversi gliserol yang cukup tinggi sebesar $98,51 \%$.

\section{Metode Penelitian}

\subsection{Simulasi Model Reactive Distillation}

Unit reactive distillation adalah teknologi baru yang dikembangkan untuk industri kimia terutama dalam produksi triacetin. Banyak penelitian telah dilakukan terkait dengan teknologi ini untuk meningkatkan reaktor dan sistem distilasi. Ada empat keuntungan yang membuat para peneliti lebih tertarik mempelajari teknologi baru ini, (i) menggeser konversi kesetimbangan, (ii) meningkatkan selektivitas produk, (iii) memecah campuran azeotropik, dan (iv) menghemat energi karena penggunaan reaksi panas untuk proses pemisahan [10]. Salah satu penelitian sukses yang dilakukan oleh Zahrul Mufrodi [11], membuat triasetin cocok untuk diproses dalam kolom reactive distillation dengan menghadirkan katalis asam sulfat menggunakan proses esterifikasi. Penelitian ini dilakukan dengan menggunakan perangkat lunak simulasi Aspen Plus. Simulasi adalah software yang digunakan dalam mengembangkan atau membangun peralatan atau teknologi baru untuk proses baru dan lama tanpa risiko kehilangan nyawa, investasi, dan waktu untuk membangun pilot plant untuk percobaan. Aspen juga pernah dilakukan untuk mensimulasikan dan mengoptimalkan proses reactive packed distillation etil asetat [12], dan butil asetat [13].

\subsection{Pemodelan Sintesis Triasetin Sistem Kontinyu}

Kapasitas produksi triasetin yang diharapkan adalah $10.000 \mathrm{~kg} / \mathrm{jam}$ dengan kemurnian mencapai 99\%. Proses simulasi dilakukan pada sebuah unit reactive distillation. Kondisi operasi pada sistem kontinyu reactive distillation di simulasikan pada suhu $115^{\circ} \mathrm{C}$ dan tekanan $1 \mathrm{~atm}$. Pada gambar 1 dapat dilihat skema unit reactive distillation yang digunakan untuk mensintesis gliserol dan asam asetat dengan katalis asam sulfat. 


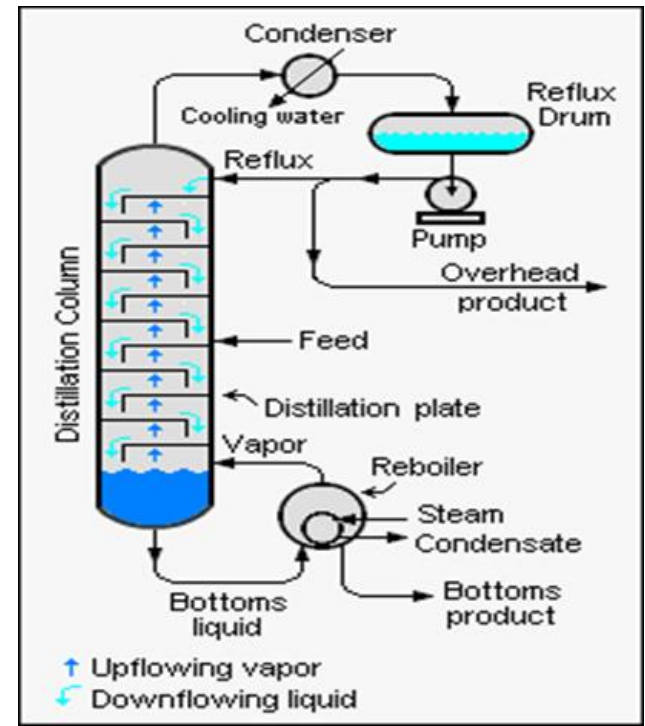

Gambar 1. Skema Desain Reactive distillation

Model sintesis triasetin sistem kontinyu dengan menggunakan reactive distillation dapat disimulasikan dengan perangkat lunak Aspen Plus 7.2. Skematik model sintesis triasetin dapat dilihat pada gambar 2. Sedangkan asumsi dasar yang digunakan pada simulasi sintesis triasetin adalah:

1. Proses simulasi yang terjadi adalah steady state

2. Kondisi proses adalah Isotermal

3. Jenis aliran adalah plug flow

Dalam simulasi kolom reactive distillation untuk esterifikasi gliserol dengan asam asetat, persamaan reaksi kimia untuk proses esterifikasi untuk menghasilkan triasetin dan air adalah sebagai berikut;

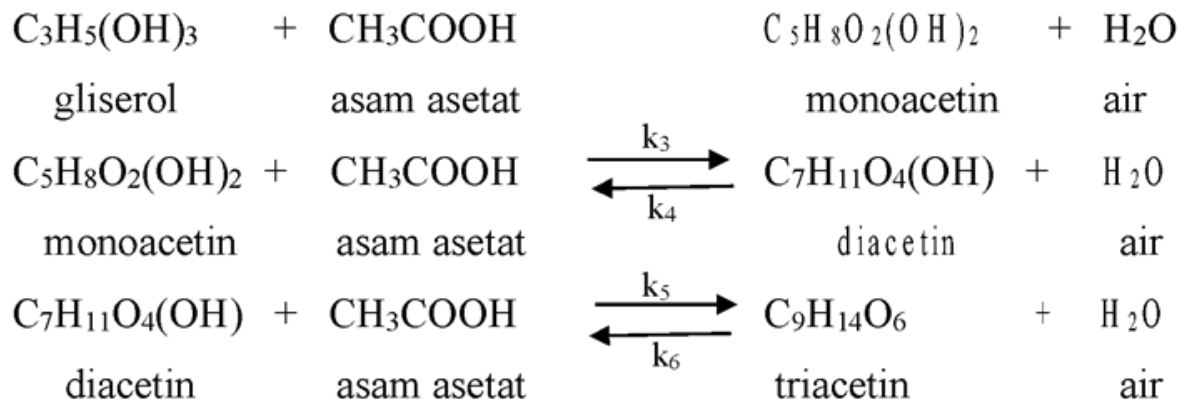

Dari studi literatur sebelumnya, ada kurangnya informasi tentang proses pembentukan Triacetin seperti data untuk diacetin. Namun, semua informasi diestimasi oleh estimasi Aspen. Untuk simulasi, fase uap diasumsikan ideal dan metode properti termodinamika yang digunakan adalah model UNIQUAC dengan estimasi untuk semua parameter yang hilang untuk mewakili koefisien konsentrasi dalam ekspresi laju.

Dalam melakukan pembuatan model simulasi terdapat langkah-langkah yang digunakan untuk membuat model simulasi sintesis triasetin sistem kontinyu dengan reactive distillation dengan software Aspen Plus: 


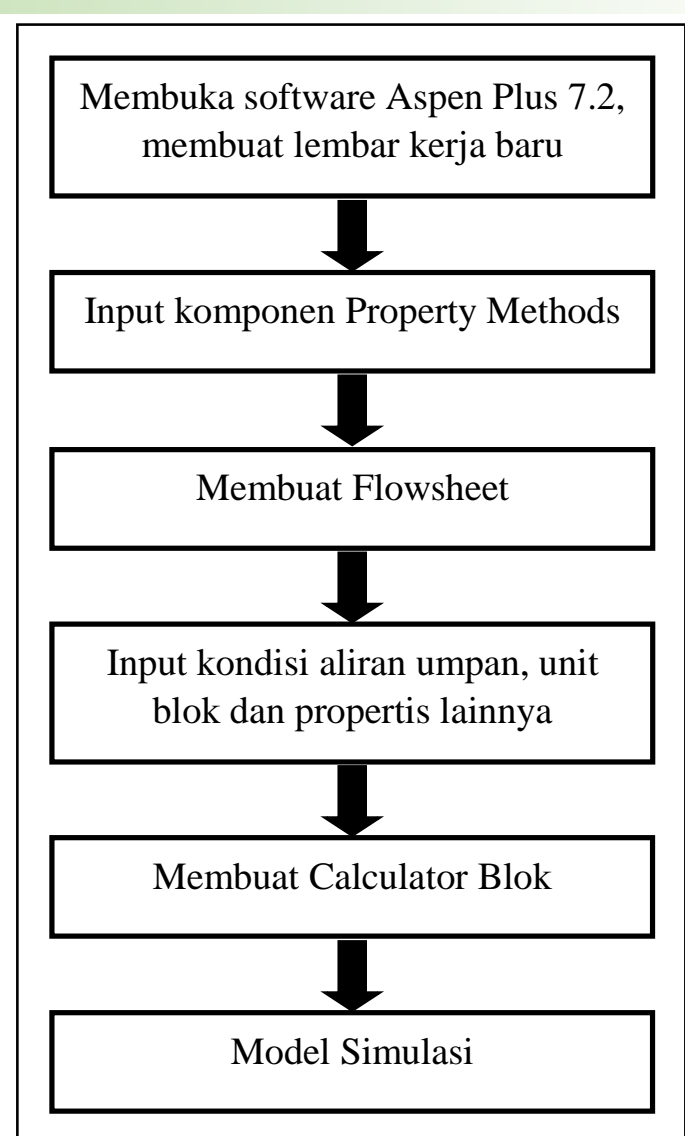

Gambar 2. Alur tahap pembuatan model simulasi pada software Aspen Plus

Pertama-tama yang kita lakukan adalah membuka software Aspen Plus 7.2 dan kemudian membuat lembar kerja baru kemudian membuat lembar alur proses, tentukan aliran umpan dan produk, dan masukkan parameter nyata dan bilangan bulat yang sesuai dengan model. Tampilan Aspen Plus dengan skema simulasi yang telah dibuat dapat dilihat pada gambar 3 berikut ini.

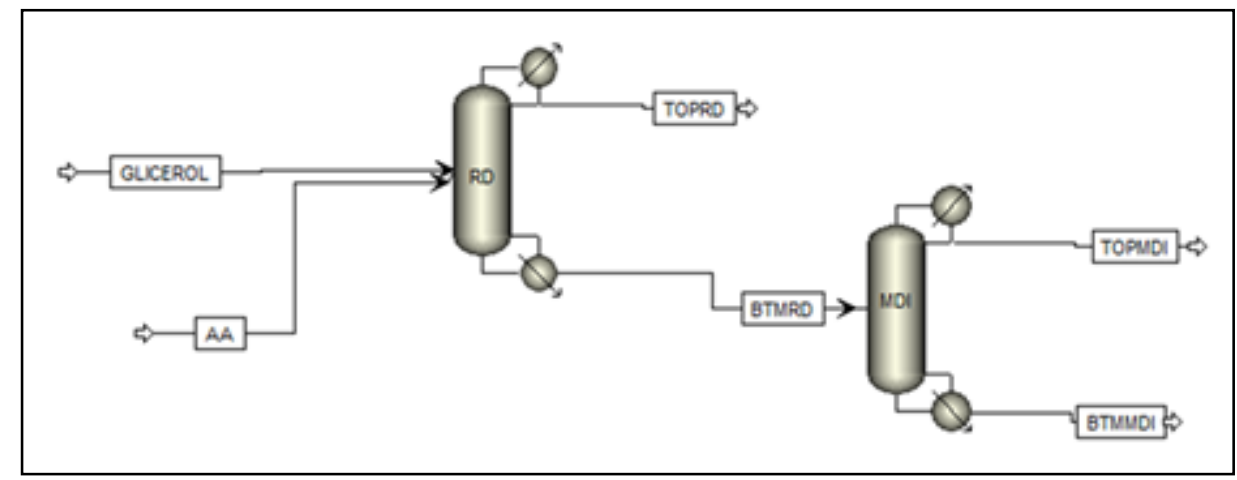

Gambar 3. Skema simulasi Aspen Plus

\subsection{Mengatur Properti}

Setiap bagian dari lembar alir proses harus diberi atribut properti parameter. Metode dan model properti harus diperbaiki terlebih dahulu sebelum melanjutkan ke langkah maju. Ini penting untuk mengetahui bahwa situasi apa yang diatur untuk disimulasikan oleh Blok. Di Aspen plus itu penting untuk membangun proses flowheet. Aspek terpenting adalah aliran yang dibuat terlebih dahulu dan akan meneruskan data ke array Aspen Plus yang berisi data aliran produk. Tampilan pengaturan pada Aspen Plus dapat dilihat pada gambar 4 berikut ini. 


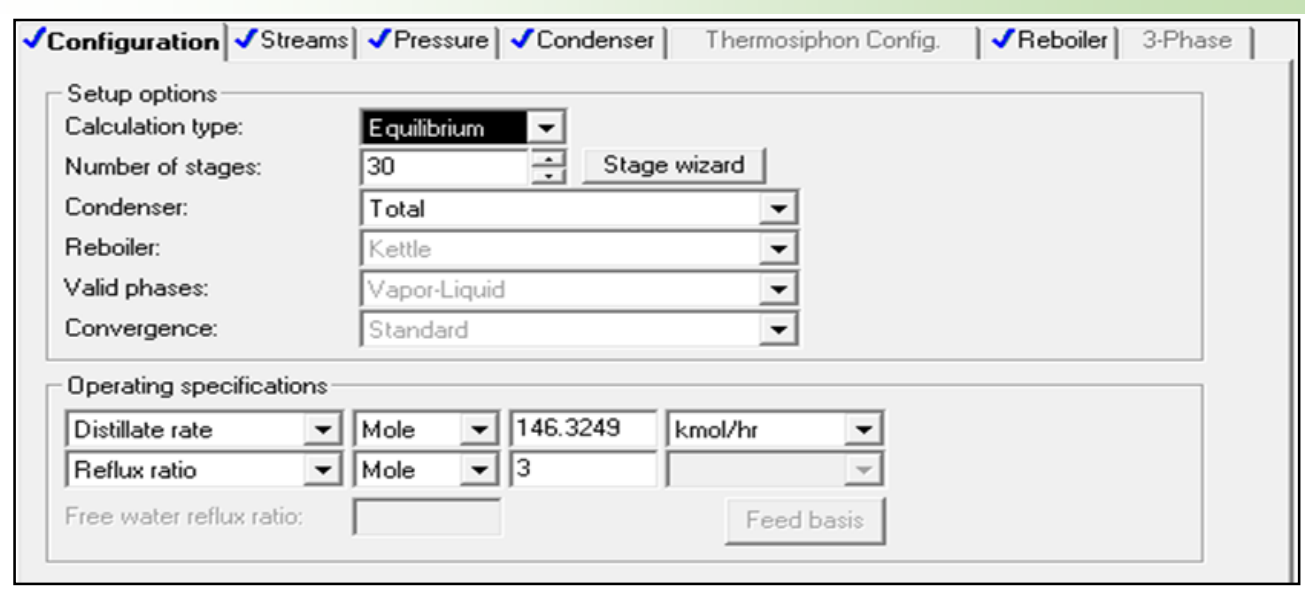

Gambar 4. Configuration of Block RD

\begin{tabular}{|c|c|c|c|c|c|c|}
\hline \multirow{2}{*}{$\begin{array}{l}\checkmark \text { Configuration } \\
\ulcorner\text { Feed streams }\end{array}$} & $\checkmark$ Streams & $\mid \sqrt{ }$ Pressure $\mid \checkmark$ Condenser & \multicolumn{2}{|c|}{ Thermosiphon Config. } & \multirow[t]{2}{*}{$\checkmark$ Reboiler } & \multirow[t]{2}{*}{ 3.Phase } \\
\hline & & & & & & \\
\hline Name & Stage & Convention & & & & \\
\hline GLICEROL & 18 & Above-Stage & & & & \\
\hline $\mathrm{AA}$ & 18 & Above-Stage & & & & \\
\hline \multicolumn{7}{|l|}{ Product streams } \\
\hline Name & Stage & Phase & Basis & Flow & Units & Flow r. \\
\hline TOPRD & 1 & Liquid & Mole & & $\mathrm{kmol} / \mathrm{hr}$ & \\
\hline BTMRD & 30 & Liquid & Mole & & $\mathrm{kmol} / \mathrm{hr}$ & \\
\hline & \begin{tabular}{l|l|} 
& \\
\end{tabular} & & & & & 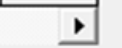 \\
\hline
\end{tabular}

Gambar 5. Simulation of Reflux ratio, number of stages, and Distilate rate

Gambar 5 menampilkan simulasi dari rasio refluk, jumlah stage dan aliran distilasi, simulasi tersebut dilakukan setelah melakukan pengaturan blok Reactive Distillation. Simulasi dan pengaturan dinyatakan tepat ketika bagian telah terdapat tanda centang biru pada bagian judul pengaturan simulasi Aspen Plus. Simulasi dilanjutkan dengan melakukan uji coba Feed Stream Stoichiometry of reaction. Tampilan uji coba Feed Stream Stoichiometry of reaction dapat dilihat pada gambar 6 sebagai berikut.

\begin{tabular}{|c|c|c|c|}
\hline$\checkmark$ Stoichiometry & ry $\mid \sqrt{ }$ Kinetic $\mid$ & Equilbrium | Conversion | Salt | Subroutine | & \\
\hline Rixn No. & Reaction type & Stoichiometry & \\
\hline 1 & KINETIC & GLYCE-01 + ACETI.01 $\Rightarrow$ MONO + WATER & \\
\hline 2 & KINETIC & MONO + WATER $\cdots$ GLYCE.01 + ACETI-01 & \\
\hline 3 & KINETIC & MONO + ACETI-01 $\rightarrow$ DIACETIN + WATER & \\
\hline 4 & KINETIC & DIACETIN + WATER ->> MONO + ACETI-01 & \\
\hline 5 & KINETIC & DIACETIN + ACETI-01 $->$ GLYCE-02 + WATER & \\
\hline 6 & KINETIC & GLYCE-02 + WATER $\rightarrow>$ DIACETIN + ACETI-01 & \\
\hline 1 & & & - \\
\hline
\end{tabular}

Gambar 6. Uji coba Feed Stream Stoichiometry of reaction. 


\section{Method}

Dari hasil simulasi yang telah dilakukan didapatkan gambaran untuk perancangan reactive destilasi yang dapat mencapai kemurnian triacetin 99\% yaitu kecepatan destilasi sebesar 146.3249 $\mathrm{kmol} / \mathrm{hr}$ untuk temperature pada bagian atas menara yaitu $100{ }^{\circ} \mathrm{C}$ dan utuk suhu bawah menara reactive distillation yaitu sebesar $222.9865{ }^{\circ} \mathrm{C}$, gambar hasil simulasi suhu atas Menara Reactive Distillation dapat dilihat pada gambar 7 sebagai berikut.

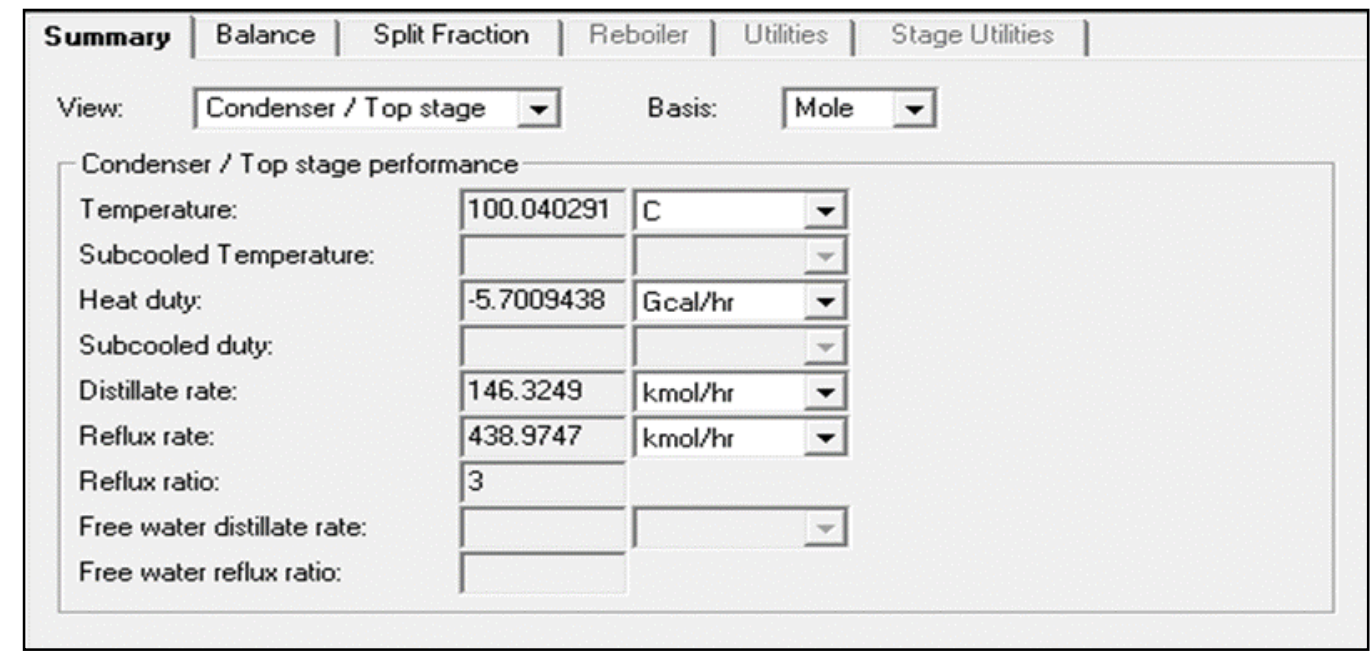

Gambar 7. Hasil suhu atas menara Reactive Distilation (Tray Sizing)

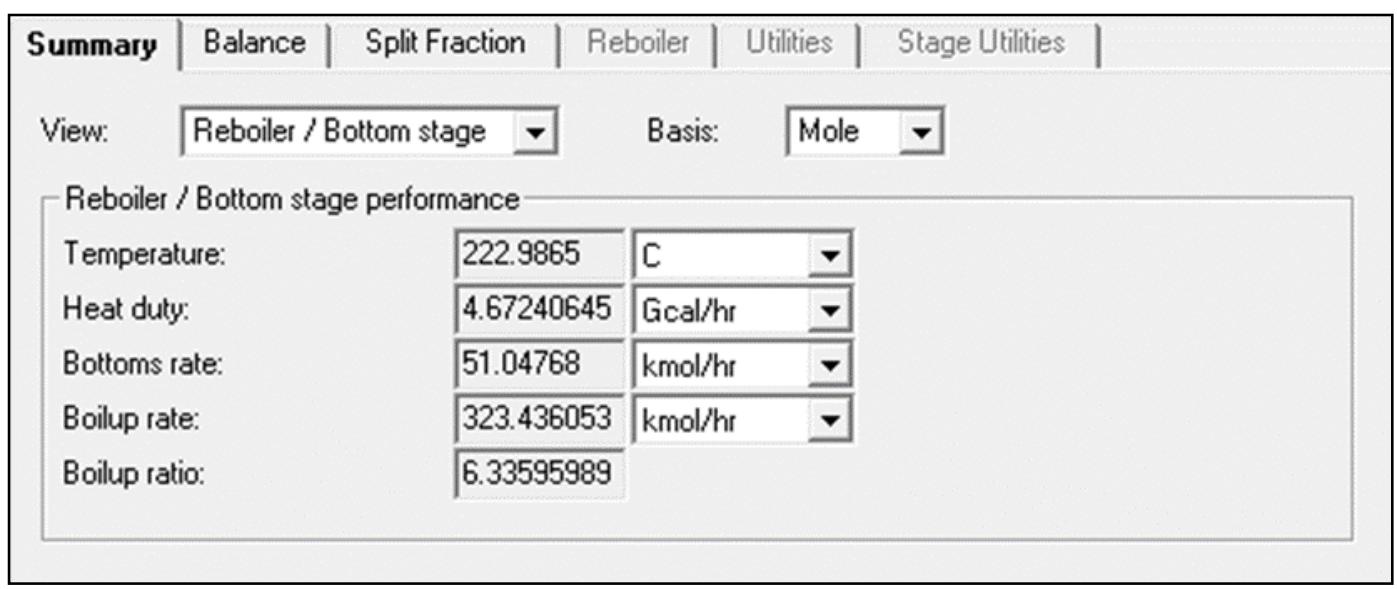

Gambar 8. Hasil suhu bawah menara Reactive Destilation

Gambar 8 merupakan hasil suhu bawah Menara Reactive Distillation, simulasi yang dilakukan menampilkan hasil beberapa spesifikasi bottom stage antara lain temperature, heat duty, bottom rate, boil up rate, dan boil up ratio. Simulasi Reactive Distillation dengan Aspen Plus menunjukan kesetimbangan neraca massa dan kecepatan massa, hasil tersebut dapat dilihat pada gambar 9 sebagai berikut.

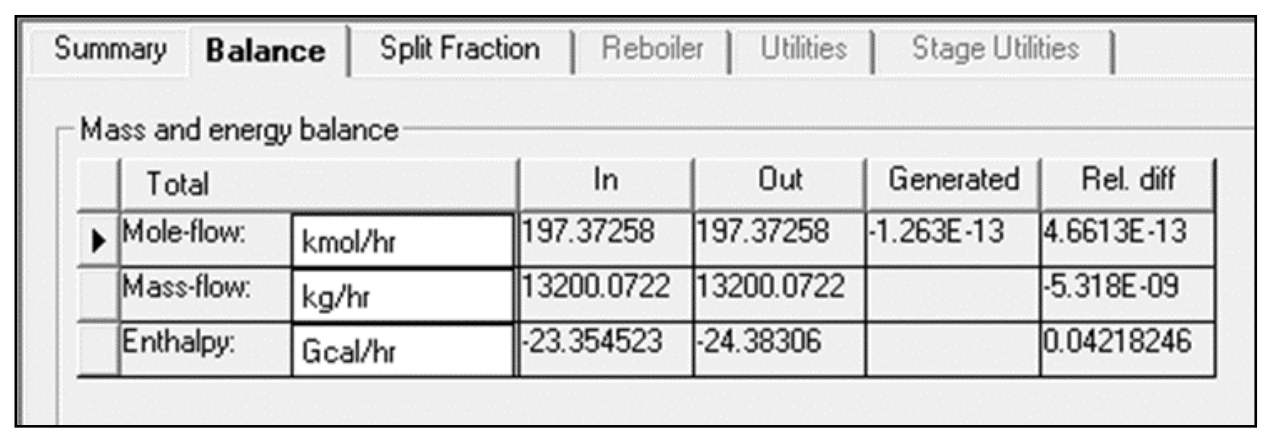

Gambar 9. Hasil neraca massa dan kecepatan massa balance 
Hasil pemisahan produk pada fraski atas dan bawah reactive distillation dapat diketahui menggunakan simulasi tersebut, tampilan hasil split fraction pada hasil atas dan bawah reactive distillation dapat dilihat pada gambar 10 sebagai berikut.

\begin{tabular}{|c|c|c|c|c|}
\hline Summary | Balance & Split Fraction & Reboiler & Utilities & Stage Utilities \\
\hline \multicolumn{5}{|c|}{ Component split fractions in product streams } \\
\hline Component & |TOPRD & BTMRD & & \\
\hline - GLYCE-01 & 0 & 1 & & \\
\hline ACETI-01 & 0.08716035 & 0.91283965 & & \\
\hline GLYCE-02 & 0 & 1 & & \\
\hline WATER & 0.99994401 & $5.5995 \mathrm{E}-05$ & & \\
\hline DIACETIN & 0 & 1 & & \\
\hline MONO & 0 & 1 & & \\
\hline ASSULFAT & 0 & 1 & & \\
\hline
\end{tabular}

Gambar 10. Hasil Split Fraction

Hail simulasi suhu setiap stage menunjukkan bahwa suhu semakin meningkat pada setiap stage. Hasil dari simulasi reactive distillation berupa profil suhu setiap stage dan distribusi cairan dan uap dapat ringkas seperti yang disajikan pada tabel 1. berikut ini.

Tabel 1. Profil Suhu setiap stage

\begin{tabular}{ccccc}
\hline No. & Stage & Temperatur $\left({ }^{\circ} \mathbf{C}\right)$ & $\begin{array}{c}\text { Jumlah Cairan } \\
(\mathbf{k m o l} / \mathbf{j a m})\end{array}$ & $\begin{array}{c}\text { Jumlah Uap } \\
(\mathbf{k m o l} / \mathbf{j a m})\end{array}$ \\
\hline 1 & 20 & 101,4953 & 569,7112 & 483,2185 \\
\hline 2 & 21 & 112,4948 & 612,0972 & 518,6635 \\
\hline 3 & 22 & 114,5512 & 655,8293 & 561,0495 \\
\hline 4 & 23 & 116,3535 & 694,5168 & 604,7816 \\
\hline 5 & 24 & 117,7270 & 724,3134 & 643,4691 \\
\hline 6 & 25 & 118,6664 & 744,8816 & 673,2657 \\
\hline 7 & 26 & 119,2623 & 758,0077 & 693,8339 \\
\hline 8 & 27 & 119,6260 & 765,2598 & 706,9600 \\
\hline 9 & 28 & 120,1254 & 727,5475 & 714,2121 \\
\hline
\end{tabular}

Tabel 2. Neraca Massa Reactive Distilation

\begin{tabular}{ccccc}
\hline No. & Komponen & $\begin{array}{c}\text { Umpan } \\
\text { (kmol/jam) }\end{array}$ & $\begin{array}{c}\text { Produk Bawah } \\
\text { Reactive Distillation } \\
\text { (kmol/jam) }\end{array}$ & $\begin{array}{c}\text { Produk Atas } \\
\text { Reactive Distillation } \\
\text { (kmol/jam) }\end{array}$ \\
\hline 1 & Glycerol-01 & 47,0869 & $1,2975 \mathrm{E}-09$ & $9,9159 \mathrm{E}-30$ \\
\hline 2 & Acetic Acid & 144,2036 & 2,7754 & 0,265 \\
\hline 3 & Glycerol-02 & - & 46,9894 & $1,6574 \mathrm{E}-25$ \\
\hline 4 & Water & 4,9049 & 0,0081791 & 146,0599 \\
\hline 5 & Diacetin & - & 0,0975 & - \\
\hline 6 & Monoacetin & - & $9,7129 \mathrm{E}-08$ & $1,0076 \mathrm{E}-29$ \\
\hline 7 & Asam Sulfat & - & 1,1772 & $1,1881 \mathrm{E}-22$ \\
\hline
\end{tabular}

Tabel 2 menunjukkan neraca massa dalam satuan kmol/jam Reactive Distillation hasil dari simulasi Aspen Plus yang disajikan dalam tabel. Hasil tersebut menunjukkan bahwa massa produk cenderung terpisah sebagai produk bawah RD. Neraca massa dalam satuan $\mathrm{kg} / \mathrm{jam}$ dapat pula diketahui melalui Aspen Plus. Hasil tersebut dapat terlihat pada tabel 3 sebagai berikut. 
Tabel 3. Neraca Massa Reactive Distilation

\begin{tabular}{ccccc}
\hline No. & Komponen & $\begin{array}{c}\text { Umpan } \\
\text { (kg/jam) }\end{array}$ & $\begin{array}{c}\text { Produk Bawah Reactive } \\
\text { Distilation (kg/jam) }\end{array}$ & $\begin{array}{c}\text { Produk Atas Reactive } \\
\text { Distillation (kg/jam) }\end{array}$ \\
\hline 1 & Glycerol-01 & 4336,455 & 0,000000195 & $9,132 \mathrm{E}-28$ \\
\hline 2 & Acetic Acid & 8659,795 & 166,6699 & 15,9141 \\
\hline 3 & Glycerol-02 & - & 10253,39 & $3,6165 \mathrm{E}-23$ \\
\hline 4 & Water & 88,36279 & 1473494 & 2631,31 \\
\hline 5 & Diacetin & - & 17,1772 & - \\
\hline 6 & Monoacetin & - & 0,000013028 & $1,3515 \mathrm{E}-27$ \\
\hline 7 & Asam Sulfat & - & 115,4592 & $1,1652 \mathrm{E}-20$ \\
\hline
\end{tabular}

Simulasi Aspen plus memberikan hasil yang sangat detail tentang spesifikasi dan distribusi umpan serta produk. Simulasi dilakukan dengan kondisi operasi alat menggunakan temperature sebesar $115^{\circ} \mathrm{C}$, tekanan $1,01325 \mathrm{Bar}$ dan laju alir massa sebesar $13200,0720 \mathrm{~kg} / \mathrm{jam}$. Hasil lain yang dapat diketahui melalui simulasi tersebut adalah neraca panas yang dapat dilihat pada tabel 4 sebagai berikut.

Tabel 4. Neraca panas

\begin{tabular}{ccccc}
\hline No. & Komponen & Umpan & $\begin{array}{c}\text { Produk Bawah } \\
\text { Reactive Distilation }\end{array}$ & $\begin{array}{c}\text { Produk Atas } \\
\text { Reactive Distilation }\end{array}$ \\
\hline 1 & Laju Alir mol $(\mathrm{kmol} / \mathrm{jam})$ & 197,3726 & 51,0477 & 146,3249 \\
\hline 2 & Laju Alir massa $(\mathrm{kg} / \mathrm{jam})$ & 13200,072 & 10552,85 & 2647,224 \\
\hline 3 & Temperatur $\left({ }^{\circ} \mathrm{C}\right)$ & 115 & 222,9865 & 100,0403 \\
\hline 4 & Tekanan $(\mathrm{Bar})$ & 1,01325 & 1,01325 & 1,01325 \\
\hline 5 & Molar Enthalpy $(\mathrm{kcal} / \mathrm{mol})$ & $-259,014$ & $-285,6806$ & $-66,9723$ \\
\hline 6 & Mass Ethalpy $(\mathrm{kcal} / \mathrm{Kg})$ & $-3505,088$ & $-1381,934$ & $-3701,885$ \\
\hline 7 & Molar Entropy $(\mathrm{cal} / \mathrm{mol} \mathrm{K})$ & $-183,3961$ & $-194,1391$ & $-34,9172$ \\
\hline 8 & Mass Entropy $(\mathrm{cal} / \mathrm{gram} \mathrm{K})$ & $-2,372$ & $-0,9391$ & $-1,93$ \\
\hline 9 & Molar Density $(\mathrm{kmol} / \mathrm{cum})$ & 29,4989 & 4,5858 & 50,7312 \\
\hline 10 & Mass Density $(\mathrm{kg} / \mathrm{cum})$ & 2153,5089 & 206,7253 & 917,7994 \\
\hline
\end{tabular}

\section{Kesimpulan}

Simulasi proses dan optimalisasi skema stabilisasi Triacetin telah berhasil dilakukan dan dikembangkan. Triacetin yang dioptimalkan menunjukkan kemurnian yang dapat mencapai $99 \%$. Oleh karena itu, telah ditunjukkan bahwa model Aspen Plus yang dikembangkan dari pekerjaan penelitian ini dapat digunakan untuk mewakili, mensimulasikan, dan mengoptimalkan sistem

\section{Ucapan Terimakasih}

Kami mengucapkan terimakasih kepada Dr. Zahrul Mufrodi, S.T., M.T. dari Program Studi Teknik Kimia Universitas Ahmad Dahlan yang telah membimbing dan mengarahkan kami dalam melaksanakan penelitian ini.

\section{Daftar Pustaka}

[1] Jomtib, N., Prommuak, C., Goto, M., Sasaki, M. and Shotipruk, A., Effect of co-solvents on transesterification of refined palm oil in supercritical methanol. Engineering Journal, 15(3), 2011, pp.4958.

[2] Galan, M. I., Bonet, J., Sire, R., Reneaume, J. M., \& Plesu, A. E., (2009), From Residual to Use Oil: Revalorization of Glycerine from the Biodisel Synthesis, Bioresource Tech., 100, 3775-3778. 
[3] Reddy, P. S., Sudarsanam, P., Raju, G., and Reddy, B. M., (2010), Synthesis of bio-additives: Acetylation of glycerol over zirconia-based solid acid catalysts, Catal. Commun., vol. 11, pp. 1224-1228.

[4] Rahmat, N., Abdullah, A. Z., and Mohamed, A. R., (2010), Recent progress on innovative and potential technologies for glycerol transformation into fuel additives: A critical review, Renewable and Sustainable Energy Reviews, vol. 14, pp. 987-1000.

[5] Rao, P. V., and Rao, B. V. A., (2011), Effect of adding Triasetin additive with Coconut oil methyl ester (COME) in performance and emission characteristics of DI diesel engine, Int. J. of Thermal Tech., 1, $100-106$.

[6] Ferreira, P., Fonseca, I. M., Ramos, A. M., Vital, J., and Castanheiro, J. E., (2009), Esterification of glycerol with acetic acid over dodecamolybdophosphoric acid encaged in USY Zeolite, Catal. Commun., vol. 10, pp. 481-484.

[7] Hou, J., Zhang, Q., Shi, W., and Li, Y., (1998), New process for synthesis of triasetin, Henan Huagon, vol. 15 , pp. 18-19.

[8] Zang, M., and Yuan, X., (2001), Synthesis of Glycerol Triacetate Catalized by Phosphotungstic Acid, Hecheng Huaxue, 9(5), 469-472. http://dx.doi.org/10.1002/jctb.2223.

[9] Mufrodi, Z., Rochmadi, Sutijan, and Budiman, A. 2012. Chemical Kinetics for Synthesis of Triasetin from Biodiesel Byproduct. Int. J. Chem., 4(2), 100-107. http://dx.doi.org/10.5539/ijc.v4n2p101

[10]Baur, R., Higler, A.P., Taylor, R. and Krishna, R., Comparison of equilibrium stage and nonequilibrium stage models for reactive distillation. Chemical Engineering Journal, 76(1), 2000, pp.33-47. [4] Mufrodi, Z., Rochmadi, Sutijan, and Budiman, A. 2013. Continuous Process of Reactive Distillation to Produce Bio-additive Triasetin From Glycerol. http://dx.doi.org/10.5539/mas.v7n10p70

[11] Mufrodi, Z., Rochmadi, Sutijan, and Budiman, A. 2013. Continuous Process of Reactive Distillation to Produce Bio-additive Triasetin From Glycerol. http://dx.doi.org/10.5539/mas.v7n10p70

[12] Abdulwahab, G.I.W.A. and KARACAN, S., 2012. Simulation and optimization of ethyl acetate reactive packed distillation process using Aspen Hysys. TOJSAT, 2(2), pp.57-63.

[13]Hanika, J., Kolena, J. and Smejkal, Q., 1999. Butylacetate via reactive distillation-modelling and experiment. Chemical Engineering Science, 54(21), pp.5205-5209. 